\title{
THE EFFECT OF TRAINING METHOD AND LEG POWER TOWARD DOLYO CHAGI ABILITY
}

\author{
Moch. Asmawi,* Ida Bagus Wiguna** \\ graduate state University of Jakarta.* \\ mochasmawi.@unj.ac.id*
}

\begin{abstract}
The objective of this research is to investigate the effect of training method and leg power toward dolyo chagi ability of taekwondo athletes. In this research factorial design $2 \times 3$ was applied. The sample of this research is 60 athletes and was chosen by purposive sampling technique. From the result of data analysis and interpretation, it can be concluded that: (1) There is difference influence between the plyometric training, saq and circuit toward dolyo chagi ability (2) There is difference influence between the strong leg power group and weak leg power group toward dolyo chagi ability (3) There was an interaction between training method and leg power toward dolyo chagi ability. (4) On strong leg power group, the ability of dolyo chagi with plyometric training method was better than saq training. (5) On strong leg power group, the ability of dolyo chagi with plyometric was better than circuit training. (6) On strong leg power group, the ability of dolyo chagi with saq training method was better than circuit training. (7) On weak leg power group, the ability of dolyo chagi with saq method was better than plyometric method. (8) On weak leg powergroup, the ability of dolyo chagi with circuit method was better than plyometric method
\end{abstract}

Key Words : Dolyo Chagi Ability, Training Method, and Leg Power

Taekwondo is one of branch of sports which can develop well and can be accepted fast in the society of all areas, proven by massive promotion of taekwondo in all provinces in Indonesia. If we analyze that fact, the achievement of taekwondo in Indonesia must be on a satisfying level. In a branch of sport with high movement ability like The coach on Taekwndo only focus on the improvement of ability without concerning ability supporting. factors which can support the improvement of Understanding toward the importance of technical ability support, such as physical and psychological condition, must be observed in order to obtain optimal achievement.

Taekwondo martial art in Lampung has experienced significantly fast development, from elementary school to university which have training units of taekwondo. Every three months, there is a local level pre junior and junior competition event held independently by Student Activity Unit (UKM) in university or training units.

The frequent competition events in Lampung make coaches compete to train their athletes to win every competition. Nevertheless, the frequent events make the long term coaching pattern do not work well.

The training of a branch of sport with high technique and skill really need good preparation, not only from movement ability factor also good physical condition. The coaches often forgot on this part high movement ability needed by taekwondo athletes cannot be separated from physical components, such as, power, speed, endurance, flexibility, and other 
biomotor components. The training pattern gave mostly targeted for movement ability, such as, basic kick and its combination, then for competition strategy, so that the foundation of general preparation is often missed.

Taekwondo competition rules which recently have changed in scoring system are (1) point for attack on the body, two (2) point for spinning kick which is allowed on the body, three (3) points for attack on the head and four (4) point for spinning kick attack on the head, of which point is given if permitted techniques are done accurately with adequately strong power on the permitted target areas. Therefore have a kick ability if the kick fulfills two aspects, namely, the first one is if the kick has enough power, the second one is if the kick is done with right techniques. Therefore, in the competition, the ability needed by an athlete is not only power for one kick but also combination kick which is very dynamic.

It also applies for competition rules which manage violation, namely, giving one time warning (kyong go) for an athlete who goes out of boundary line, and every two time warning (kyong go) so that the athlete will have gam - jeom (the addition of one point for opponent), then if the athlete gets eight (8) kyong-go or four (4) gam - jeum, the referee directly states that the athlete who gets that penalty loses because of the penalty. The rules as mentioned above make athletes have kicking ability which is more cyclic power and combined with changing direction ability in order not to be trapped to be out of boundary line which may result in warning and violation.

The Training for improving muscle condition which is popular to be applied is plyometric which is reputable to improve maximal power, especially leg muscle power. In addition to plyometric training, circuit training is also used frequently as one of methods to develop the whole muscle condition. In circuit training, the form of training consists of various forms of training for certain needed condition.

The next training can improve muscle condition Currently, weight training is quite popular. When not many people prove any satisfying results from weight training, many people believe that weight training will only result in strong muscle condition, but slow, while some researchers conclude that there is a very significant improvement on muscle strength as a result of weight training. The next training method for improving dolyo chagi ability is speed and quickness (saq) training. This training needs very dynamic movement, the fast change of movement direction, both the movement which has been made in pattern before and instructed movement pattern which must be followed by athlete.

Concerning many problems existing, the research is limited on difference of taekwondo athlete's kicking skill in Lampung Province through training method which is related to dolyo chagi ability, the training methods which will be studied are training methods which have similar characteristic, namely, training methods which both of them use internal weight. Training methods are differentiated to be (1) Plyometric training method (2) Speed, agility, and quickness (saq) training and (3) circuit training, while the attribute variable is leg power which is differentiated to be (1) strong and (2) weak. Training method and leg power are independent variables and dolyo chagi ability is a dependent variable.

In order to get more focus on the studied problems, the problems can be formulated as follows: (1) Is there a difference of dolyo chagi ability resulted from Plyometric, saq, and circuit trainings in total? (2) Is there a difference of dolyo chagi ability between strong leg power and weak leg power in total? (3) Is there an interaction between training method and 
leg power toward dolyo chagi ability? (4) Is there a difference between plyometric training and saq training on taekwondo athlete with strong leg power? (5) Is there a difference of dolyo chagi ability between saq training and circuit training on taekwondo athlete with weak leg power? (8) Is there a difference of dolyo chagi ability between plyometric training and saq training on taekwondo athlete with weak leg power? (9) Is there a difference of dolyo chagi ability between saq training and circuit training on taekwondo athlete with weak leg power?

\section{Dolyo Chagi Ability on Taekwondo athlete}

Kick is a unique characteristic of taekwondo competition where in taekwondo branch of sport, kick is called as chagi. Athlete who participates in competition must be skillful in performing kicking movement, which is supported by additional movements, such as, step and spinning. The skillful movement which is expected to be gained from basic movement pattern training theoretically is a movement resulted from three factors, namely, individual factor, duty factor, and environment factor (Anne Shumway, 2001:2).

According to Bompa (2009:3), training is a systematic sport activity is a long term, improved progressively and individually toward characteristics of human physiological and psychological functions in order to achieve the determined goal. The training which is done systematically, seriously, regularly and there is an addition of training weight step by step and continuously which will affect body organs. Movement ability or called as motor ability is basically genetic inheritance which cannot be totally changed, but can be improved by improving specific movement or skill in it. To improve movement ability totally, specific ability trainings are needed to support total movement ability (Cheryl A Cocer,2004 :13).

According to William H Edward (2011:9), ability is a very specific component and must be trained, and is influenced by one's motoric control and motoric learning. The Ability influenced mostly by one's movement character with the foundation of ability or can be resulted from some specific abilities. Nevertheless, ability is also supported to give contribution to skill, therefore, from the above theory, it can be concluded that skill is a specific ability while ability is a component which is totally resulted by specific movements or skill. While, according to Bruce Abernety in David L Galahue (2006:16), skill is an activity done by movement of body, involving parts of body, to get the expected movement. Thus, in forming ability of one's movement ability, skill analysis is needed to support the skill. In dolyo chagi ability, the first expected skill is that athlete can perform kicking movement accurately on the target, and the second expected skill is after kicking, the athlete can perform changing of direction and the next kick. Therefore, there are two components which become concern namely skill training of dolyo chagi itself and its agility.

In taekwondo, athlete uses more kick than blow because taekwondo is a long distance martial art. Dolyo chagi is the mostly used kick in taekwondo where dolyo chagi is used as much as $50 \%$ in the competition and even from all kicks in taekwondo competition, $85 \%$ of its score is resulted from dolyo chagi (Young KwanKim, 2011:31).

According to Yoyok Suryadi (2002:34), the way to perform dolyo chagi is by doing waist spinning in order to collect power from body weight, by tip of forefoot ( $a p$ Chuk), but it is also often performed by instep (baldeung) especially in the competition. On dolyo chagi kick, the first thing to occur is movement of body parts which cause the reduction of angle 
between bone and joint (fleksi) on the waist, upper limb and lower limb which is folded as the athlete moves upward that will reduce obstacle (inertia) from leg in total (Gerry Car, 2004 $: 191)$.

The movement is identical with movement on leg curl in weight training where muscle involved in such movement dominantly consists of hamstring muscle: semitendinosus, biceps femoris, long head, semimembranosus, biceps femorie waists, and short head. Ollowed by internal rotation movement supported by endorotation muscle (James Tangkudung, 2006 :38). Next, the second movement is done namely internal rotation movement which involves joint on waist line and leg, hip joint (articulatio coxae), knee joint (articulatio genu), joint of shin (tibiofibular joint) in this way will occur pivot movement on the legs which support body (articulatio talucruralis) (Suranto : $2004: 31$ ), where there is an external rotation movement on the leg which support body (Robert Behnke,2006:29), in this second stage will really determine quality of dolyo chagi because hip flexibility will be really influencing in hip rotation and it will influence leg.

Third movement is continued by releasing kick, done by straightening leg (extension), where a part of feet which hit the target is instep. Dolyo Chagi can be also called as roundhouse kicks, where this kick has many variations of movement. From a survey, this kick is mostly used in the competition. The way to do it is by having stance position ap seogi (stance of punching), move leg upward by folding knee, then with the help of hip, leg is kicked spinning as half internal rotation and straightened into the target, where part which hits the target is instep (Bill Pottle \& Katie Pottle,2013 :31). Pivot on leg pedestal and hip movement are important points in performing dolyo chagi. In addition, leg fold will also help kick power done. From those above it can be concluded that dolyo chagi is a form of kick in taekwondo, where the form of kick is at the kick with half internal rotation and the part of feet which hits the target is instep.

In taekwondo competition, it is not only needed basic kicking ability but also ability to form attacking pattern and defending pattern. The movements needed are the very dynamic and fast movement so that athlete can do the movements many times by changing directions fast so that taekwondo athlete needs agility of movements.

According to Jay Dawes (2012:7), agility is one's physical ability which enables one to change the body position fast in the right and accurate way. In taekwondo competition, change of position is done based on the need in competition. Athlete is expected to adapt the court condition and both attack mechanism and defense of opponent, so that agility has an important role in taekwondo competition.

Characteristic of agility is fast hand and feet, body coordination, and fast reaction (John Shepherd, 2009:41). Agility is an ability to slow, accelerate, and do body movement fast by keeping control and body position without reducing speed when doing the movement. According toLee E Brown (2000:80), agility is strongly related to balance because when an athlete does the movement of body position, he should maintain his balance so that there is no unexpected body movement due to the movement done.

Agility is an ability of changing position fast (Hoffman Jay,2006:12). Agility us also supported by other physical ability, such as, explosive power, speed, and coordination. By agility, an athlete will have good mobility level (Bompa \& Gregory Haff, 2009:326).In sport, agility is shown by fast leg movement and good coordination while body changes direction, 
good reaction time, so that agility is a complex combination between balance, speed, strength, flexibility, and coordination (Jhon Shepherd, 2007:82).

From the explanation about definition of movement ability and dolyo chagi, do movements which change direction fast without losing balance and keep doing ability in the branch of sport, while dolyo chagi is a form of front kick with the form of half circle which is a basic kick combined with steps, such as steps to the side, back, and forward.

\section{Training Methods}

In this research, there are 3 training methods given to each group to be studied. According Chaterine Dawson (2007 : 15) method is a way used to obtain data and then use that data to get certain results. By the above definition, training methods are wellprogrammed methods functioning as tools to present series of sport activities in order to increase the expected functions of physiological, psychological and motor skills. To gain the expected dolyo chagi skill, training methods will be given in this research are methods of plyometric, SAQ (speed, agility and quickness), and circuit.

Plyometric is a very well-known training form among the taekwondo coaches and its training characteristics include the activities of jumping or bouncing limbs. Plyometric was first introduced in 1975 by Fred Wilt, one of the American track and field coaches. It is originated from Latin Plio + metrics which mean measuring the improvement (Thomas R. Baecele, 2008:414).

Based on intensity, plyometric training is classified into some types. Sam Bordis specifically divides the intensity of plyometric training into light intensity, which is standing based jumps training type e.g. tuck jump, split jump, and squat jump. Plyometric training with light - medium intensity is jump from standing training type e.g. standing long jump, standing hop, standing jump for height (Sam Bordis, 2006:57).

This research will apply plyometric training with light intensity i.e. category of jumps in place and standing jumps. The first is jumps in place that consists of two foot ankle hop, double leg tuck jump, pike jump, and squat jump training types.

By the above explanation, it can be analyzed that plyometric training is a training methods with forms of bouncing limbs and muscles with maximum body movements and is carried out explosively. Plyometric training results in strain and quick shortening of muscle contractions, all muscles - large muscles supporting the body movements involved in this training and may change the muscle mass or known as hipertropy. The plyometric training used in this research is plyometric with light intensity or low impact with volume of $60-100$ in a week in which the percentage against the exercise repetition for each person made to be equal considering the used exercise form is low impact plyometric and athletes are grouped based on the same conditions of power leg.

Training of speed, agility and quickness is pretty popular in taekwondo. This training combines the speed, agility and quickness or SAQ. SAQ training is mostly used in soccer or athletics during the training camp. This training method has been around for a long time and developed into various SAQ exercise forms. SAQ training may improve the speed, power and ability to bring out the maximum power as long as change the high speed. In addition to that, SAQ training may also simultaneously form the muscle power, improve the complex 
movements, improve the brain ability against the coming signs, help the whole movements and increase the reaction time (Paul Collins, 2009:70).

The ability to change direction and speed and change movements according to the required conditions become very important to notice. That speed change is resulted by the muscle elasticity to do immediate movement and shorten as soon as possible after the muscle elongation. Therefore, principally the physiological impacts on SAQ training is almost the same with plyometric training but it is more into small muscles and most about immediate change of direction than long and high jumps (Lee E Brown, 2000:6).

SAQ training is most carried out by SAQ training movements consisting of speed, agility and quickness exercises. These three components stand alone with each characteristic and purpose of training. According to Ian Jeffreys (2013:1), movement speed of a person may be affected by his/her muscle fibers i.e. white muscle fibers and red muscle fibers or combination of fast muscle fibers and slow muscle fibers and those fibers are define by his/her genetic factors that those muscle fibers may not change by trainings.

White muscle fibers of Fast - Twich Fiber has the ability to do potential movement transmission, an activity by Myosin and produces high ATP by rapid calcium release and absorbed by sarcoplasmic reticulum and all of these produce an ability of quick energy transfer used by muscles to move fast and strong contractions. Slow - Twist Fiber produces energy by re-synthesizing the ATP which means it requires a pretty long transfer time of aerobe system and it characterizes the myosin activity in producing low ATP that causes slow contractions and glilolisis capacity may not developed properly by Fast - Twich Fiber (Robert Frost, 2002:15).

Though the speed is affected by fiber muscles, there are many other factors that may increase the speed such as strength and technique in sports. Speed may be defined by the height of arms and legs movement, length of steps or combination that it requires trainings to improve the condition of steps and arms swing. Speed trainings cause adjustments similar to the adjustment process in strength training rather than the adjustment process in resistance training (Paulus Pesurney, 2008:14).

Agility is the ability to slow down, speed up, and to shift the body quickly which still maintains control over the position of the body without reducing the speed when performing the movement. Agility is closely related to balance because in shifting body position, an athlete is affected by center of gravitation from his/her body, an athlete must be able to maintain his/her balance hence there is no unwanted body shifting occur as a result of the movement done by her/him, hence the agility is also affected by the ability to forward the information received from the brain to the nervous system to be continued to movement (Churchiil Livingstone,2004:115).

If quickness is analyzed, his definition is similar to speed and agility, but in quickness the brief movement of the stimulus that comes with these movements follow a certain pattern and must be done with movements that are also appropriate. The improvement of quickness is greatly effected by the speed increase, acceleration and reaction time. The faster the brain sends signals to the body, the more rapid the movement; but still, concentration is the key to the formation of quickness. At quickness drills, nerves are expected to receive the stimulus (Lee E Brown, 2000: 147).

From the characteristic of Speed, Agility, and Quickness (saq) trainings that has been 
described can be concluded that the trainings of Speed, Agility, and Quickness (saq) are training methods to improve agility, with rapid body movements training character, the movement of feet will be fast and move their direction to follow a certain pattern of movement or movements which have no pattern before.

Sports skill is strongly supported by many kinds physical condition components, the development of one physical condition and the others are all interrelated, there is none that stands on its own. Good conditions need to be developed maximally and in its development requires a long time, but in facing a match, the coach sometimes has less than two months to face the match, while all physical components are required to be ready for the match, plus the importance of skills training in each of their respective sport.

Due to the very short time given, the coach is not performing a specific component in accordance with the training principles. But we can not ignore the physical condition training at all, because physical condition plays a very important role in a match. The dolyo chagi ability that is expected in this research is the ability to do dolyo chagi while doing direction change movements without losing the balance, of course, to maximize that ability coordination of all components of the body is needed, due to changes in direction and kicking skill that is unified to produce motion skills, hence coordination of all components of the body is required.

According Bompa (1999:29) there are five basic provisions to improve someone's muscle. The first is to improve the quality of joints because in training activities there will be the movement of the joints such as knees, ankles, and thighs. The good condition of joints will help in good motion quality. The second is to develop the strength of the tendon. The third is to develop the strength of middle muscles such as abdominal and lower back, because good middle muscle will help in jumping movement and direction change hence it can be done optimally. The fourth is to improve the balance. The last one to train the strength according to the movements in the sport. The movement of the entire body does not stand alone; a good body movement is produced by coordination of all body muscles. From that study, circuit training is also expected to improve the dolyo chagi ability of taekwondo athletes.

From the description above, the circuit training to improve the dolyo chagi ability in this study is a training to improve muscle quality, both the strength and coordination. In the training post, it can include Shuttle Runs training, continued to the second post with push-ups training, the third post with squat jump training, the fourth post with sit up, the fifth post with squat trusts, the sixth post with Tuck Jump with knees up, the seventh post with split pike jump, the eighth post with crunches, the ninth post with floor kip, and the last post with $100 \mathrm{~m}$ run.

\section{Leg Power}

Power is where strength and speed are combined, or sometimes also called as rapid strength (Rainer Marten, 2004: 321). According to K Brich and D Maclaren (2005: 138) power is the ability to produce a large amount of energy in the shortest possible time. Therefore, strength becomes the supporting factor of power, strong muscles will make rapid movements with high power, hence in training power should also involve the speed of motion in it.

Power is different from strength because power is produced by quick strength; but 
new power can be formed when a person has had a good strength, power training must be preceded by a strength training preparation. It is very important to get muscle strength increase in advance. If strength training is done well prepared, it will also affect the body's ability to carry out strong and fast movement which indirectly will develop power that is needed in motion (John Shepherd, 2009: 25).

Training which is often done to increase power not only involves weight training or weight lifting but it always involves other physical activities such as running activity and other activities where there is a movement to get the desired results with limited activity, but the activities undertaken should not be performed by involving too much cardiovascular system. The increase in muscle size will increase the strength and power automatically, because power can only be produced by the time taken in work result dissertation with great power (Shirl J.Hofman, 2009: 307), therefore, the strength training should give a specific effect on the muscle, nor the heart and nor the vascular system.

Power referred in this research is the power which is produced by the leg muscles, i.e. the power to make the leap, and the direction shift of the movement using parts of the body from the groin to bottom. With a good leg power, the athletes not only have a perfect appearance at sport matches, but also will affect the adaptations on the trainings given, the athletes with a high leg power certainly have a different tolerance to various forms of training compared to the athletes who have a low power leg. Therefore, in this research leg power is considered as an attribute variable that will affect the outcome of the training on dolyo chagi ability, to minimize the effect of power leg on the success of the research, hence there will be groups based on strong and weak power leg which is dominant in taekwondo movement.

\section{The Differences of the average dolyo chagi ability between plyometric, saq and circuit training methods as a whole.}

Dolyo chagi ability is not only formed by trainings with the characteristic of shifting direction quickly, the dolyo chagi ability is formed by many components, the most dominant is the agility and motion skills. Tests carried out to see someone's agility, using indicators of capabilities of a person's motion changing and rapid direction shift without losing balance. Plyometric trainings have explosive characteristic and it trains muscles to perform body shifting by doing a far or high jump, which is of course this training characteristic will take effect on the dolyo chagi ability.

Plyometric has many forms of movement with an intensity that is different from the characteristics of upward and forward jumping movement and ended by sprint movement. While circuit training is basically a method of training to develop strength and overall physical condition, circuit training is a program that is often developed because of the development of the power with circuit training as the central component in achieving athletes successful skill and support the development of others such as durability of heart, muscle endurance and power. It means that circuit training does not only improve leg muscle condition butalso improve overall body strength.

Saq and circuit trainings are forms of training that aims to improve muscle condition related to the dolyo chagi agility, both training methods have similar characteristics but in saq training, its training form leads more to sports movement with randomized intermittent type, dynamic, and skill movement type sports (RIDS), where the athletes must follow the pattern 
formed and must follow the patterns given and patterns given suddenly. Saq training can have a significant effect on speed, even other supporting components. Based on description above, there are different levels of ability among the athletes of dolyo chagi treated with plyometric, saq and circuit training methods.

\section{The Differences of the average dolyo chagi ability with the leg power and the leg power as a whole.}

Leg is the main driving power of the body when performing sports skill movement, especially kicking movement in taekwondo like dolyo chagi. In sport, movement speed is very necessary and in martial arts that require rapid movements and also power. Leg power can be defined as the ability of leg muscles to move strongly and quickly. With strong leg muscles there will be different movement quality of each individual to adapt to a given training. Strong and quick leg muscles will receive high- intensity training well and may not be adapt maximally to this form of training with higher intensity, and therefore physiological adaptation will have different effect in every form of training. From the description above, it is expected that there are different dolyo chagi ability between the athletes with a strong leg power and the athletes with weak leg power.

\section{The Interaction between the training methods and leg power on dolyo chagi ability.}

As explained before that power is essentially result of strength and speed, power is the size of a force that can be applied to the speed, therefore it is very necessary by most sports that require a dynamic speed motion such as sprint, jumping, throwing, weightlifting and sports that require sudden body movement. From the analysis of some theories, it can be analyzed that the leg power will support any movement of anyone, not just at the time of it performs in a game but also in the implementation of training, training methods given in this research are saq training method, circuit training method and plyometric training method, which are strongly effected by leg power. However athletes leg power gives different effects on the results of the training to improve dolyo chagi ability, so there is interaction between the trainig methods and power on dolyo chagi ability of taekwondo athletes.

The Differences in the average dolyo chagi ability between plyometric training method and the training method on taekwondo athletes with strong leg power.

Plyometric a training consists of upward and forward jumping movements. Based on movement analysis, plyometric trainings require a greater force in the implementation, plyometric trainings require muscle conditions, a good tendon, even in the plyometric level with high-impact intensity of plyometric trainings must go through training prerequisites in advance. While a saq training is promoting changes of dynamic movements with irregular footsteps, following the pattern of movements forward and backward, to right and left. While saq trainings will form a good motion skills. Based on the description above, it is expected that there are different levels of ability among dolyo chagi athletes treated with plyometric training methods and the saq training method on strong leg power. 
The Differences in the average dolyo chagi ability between plyometric training method and circuit training method on taekwondo athletes with strong leg power.

Plyometric prioritize explosive training, especially focuses on leg muscles. Plyometric trainings require sudden leg movement that aims for the change in muscle condition. Basically in circuit training most forms of training consists of plyometric trainings but the model of training is done differently, where the form of circuit training is regular from agility training, upper body muscles, middle body muscles, lower body muscles, but in plyometric training all forms of training focus on the muscles of the leg. Therefore, differences in characteristics between circuit trainings and plyometric trainings will be affected by the level of leg power possessed by athletes. Circuit training emphasizes the establishment of a physical component as a whole, especially the muscular component formed including in the area of circuit training. In this study there are agility training and forms of other trainings that improve body condition as a whole, with the expectation that the formation of all physical component can support the formation of dolyo chagi optimally. Based on the description above, it is expected that there are different levels of dolyo chagi ability among the athletes treated with plyometric training method and circuit training method on strong leg power.

The Differences average dolyo chagi ability between saq training and circuit training on taekwondo athletes with strong leg power.

Leg Power is an important component that is often enhanced to improve taekwondo athlete's performance, with good leg power an athlete will be able to kick to the target quickly and strongly. Good leg Power will also give athletes the opportunity to change direction quickly, such as rotating or dodging. The athletes who have good leg power automatically have good strength because power is a combination of strength and speed, which is also called fast power. The athletes who have good leg power would be ready to receive training well, trainings that are explosive and requires high jumping power require the athletes to have a good leg power to maximize training results while avoiding the injury mainly on ligemen due to the sudden movement. Based on the description above, it is expected that there are different levels of ability among athletes dolyo chagi treated with saq training method and circuit training method on a strong leg power.

The Differences of the average dolyo chagi ability between plyometric trainings and saq trainings on taekwondo athletes with weak leg power.

Training that involves muscle contraction not only bring changes towards a better muscles, but also allows muscles to be in bad condition and even resulting in injuries if the trainings given do not have good programs and given to athletes whose conditions do not suit this training. Injuries due to training in general obtained because of a lack of preparation before training, and can also due to the condition of the athlete to adapt himself/herself in the given form of training. Based on the description above, so it is expected that there have differences in the dolyo chagi ability level between the athletes treated with plyometric training method and the saq training method on weak leg power. 


\section{The Differences of the average dolyo chagi ability between plyometric trainings and circuit trainings on taekwondo athletes with weak leg power.}

The dolyo chagi ability is built by various components especially the condition of strong muscles. Athletes who have weak leg power certainly also have low power so the explosive training has risks on the ligament injury and other components. Therefore, to increase kicking agility on athletes who have weak leg power can be done by the training method that does not require muscle contractions that force the ligament to work maximally.

Based on the description above, it is expected that there are different levels in dolyo chagi ability between the athletes treated by plyometric training method and circuit training method on weak leg power.

The Differences of the average dolyo chagi ability between saq training and circuit training on taekwondo athletes with weak leg power.

Power is a combination of strength and speed, the athletes who have strong leg power can be ensured to have high muscular too, leg power itself does not only affect the results of the training but will also greatly affect the training process because the training which involving muscle contraction will depend on the strength of muscles owned by the athletes. The strength in athletes can not stand alone mainly if the expected strength will support agility, because agility requires improvement of overall muscle components.

Based on the description above, it is expected that there are different levels of dolyo chagi ability between the athletes treated with saq training method and circuit training methods on weak leg power.

\section{METHOD}

This research aims to investigate the difference between the ability of dolyo chagi on taekwondo athlete in Lampung Province with training method and power of leg. Specifically to know the differences of the plyometric training method, speed, agility, quickness (saq), and circuit training as well as the training on strong leg power and weak leg power on the ability of dolyo chagi. This research was conducted within (6) weeks with 3 times meeting which started in April 2014.

The Method that was used in this research is quasi experiment method. Research method used is experimental research method with the $2 \times 3$ factorial design, it will give treatment on the samples with free variable, which is practice method consists of plyometric training, saq, and circuit training, and leg power that consists of strong leg power and weak leg power. This research aims to see the differences of each variable on the dolyo chagi ability of taekwondo athletes in Lampung Province, which is a dependent variable. The population in this research by noticing the large area of Lampung Province and a quite large number of training units exist in every Regency or City, and remembering the limitations of the researcher hence it is necessary to decide the accessible population.

There are three Regencies that were selected as accessible population to represent Lampung Province. Hence, from the regencies, some practice units were selected; the ones that are considered having the same characteristic by cluster random sampling, such as the same practice history, same trainer and trainer level. Hence the population obtained in this 
research comes from Lampung Tengah, Lampung Timur, and Kota Metro regencies with the total number of taekwondo athlete based on the data of taekwondo belt exam on $9^{\text {th }}$ March 2014, which is 355 people.

Based on the existed total of population that is 355 people, hence the samples were decided by purposive sample technique, which the whole population is classified based on gender, age, and belt level, sampling classification is that the taekwondo athlete of Lampung Province, male, in the age of 16-18, and are in the geup 7-4 belt level, hence the total sampling was 112 athletes.

Furthermore, sample taking was conducted to group athletes in high power and low power by using leg power test, using standing board jump test on the samples to determine the experimental group. According to Verducci sample taking can be conducted by taking $27 \%$ upper limit and $27 \%$ lower limit, for athletes whose test results are $27 \%$ above are categorized into groups of strong leg power, and those whose test results are $27 \%$ below are in the category of weak leg power (Sugiyono, 2007: 180).

In addition, each group cell, whether a group of athletes with a strong leg power or weak leg power, treated with plyometric, saq, and the circuit training methods. Grouping athletes into training method group using a random method. Hence, each cell or group gets a total sampling of 10 athletes. The instrument is to measure dolyo chagi ability is by using dolyo chagi ability test instrument, where athletes do dolyo chagi quickly and legs take turn in moving to four directions; to the front side, left side, back side, and right side. Collecting leg power data using standing board or long jump test. This test is to measure the athletes' leg power when they jump to the front side.

Data analysis requirement test that are used are normality test and variants homogeneity test. Normality test technique use Lilliefors test, and on that test, the data is considered normal if $\boldsymbol{L}_{\text {hltung }}<\boldsymbol{L}_{\text {Tabel }}$

Homogeneity test is necessary to find out that the groups come from a homogenous group. Homogeneity test is conducted by Bartlett test. Data is considered homogenous if $X_{\text {Hltung }}^{2}<X f_{\text {abel }}$

\section{RESULT}

This research hypothesis testing uses two-way variants analysis technique (ANAVA) with factorial design of $2 \times 3$.

The credence level used for the testing was $a=0,05$. If the hypothesis testing is significant then it will be continued by Scheffe test. Tukey test is used to see better interaction effect.

\section{Hypothesis Testing}

Based on ANOVA table, it can be concluded that there are differences in the dolyo chagi ability among the groups of plyometric, saq, and circuit training methods.

Furthermore, to see which group is different, Tukey test was conducted. 
Table 1. Research Design

\begin{tabular}{|l|c|c|c|}
\hline \hline \multirow{2}{*}{ Leg Power (B) } & \multicolumn{3}{|c|}{ Training Methods (A) } \\
\cline { 2 - 4 } & Plyometric (A1) & SAQ (A2) & Circuit (A3) \\
\hline Strong (B1) & & $\boldsymbol{A}_{2} \boldsymbol{B}-\boldsymbol{I}$ & $\boldsymbol{A 3 B}-\boldsymbol{L}$ \\
\hline Weak (B2) & $A_{1} B_{2}$ & $A_{2} B_{2}$ & $A-3 B_{2}$ \\
\hline Total & $A 1$ & $A_{2}$ & $A 3$ \\
\hline
\end{tabular}

Explanation:

$A_{3}=$ Dolyo chagi ability group given plyometric training method.

$A_{2}=$ Dolyo chagi ability group given saq training method.

$A_{3}=$ Dolyo chagi ability group given circuit training method.

$A_{l} B_{I}=$ Dolyo chagi ability group given plyometric training method on the strong leg power.

$A_{1} B_{2}=$ Dolyo chagi ability group given plyometric training method on the weak leg power.

$A_{2} B_{1}=$ Dolyo chagi ability group given saq training method on the strong leg power. $A_{2} B_{2}=$

Dolyo chagi ability group given saq training method on the weak leg power.

$A_{3} B_{3}=$ Dolyo chagi ability group given circuit training method on the strong leg power. $A_{3} B_{2}$

$=$ Dolyo chagi ability group given circuit training method on the weak leg power

\section{DISCUSSION}

The Average ability of dolyo chagi among the athletes given the training methods of Plyometric (A1), SAQ (A2), and Circuit (A3)

From the Anova calculation, it is shown that the score is Fhitung > Ftabel $(18,117)>$ 3,168 ), hence $\mathrm{H}_{0}$ was rejected, which means there are differences in the average ability of dolyo chagi on the three training forms. In addition, when the average score is $u_{A} * u_{A l} * u_{A}$ $(53,63>$

$50,29>46,08)$, hence the average among the three training forms is different from each other.

The average ability of dolyo chagi between the athletes with strong leg power (B1) and weak leg power (B2)

From the Anova calculation, it is shown that the score is Fhitung > Ftabel $(163,145>$ 4,020), hence $\mathrm{H}_{0}$ was rejected, which means there are

differences in the average ability of dolyo chagi on strong leg power and weak leg power. In addition, when the average score is $u_{B} * u_{B l}(56,55>$

$43,45)$, hence the average between the two groups of leg power is different from each other. 
Table 2. Data of summary of Descriptive .

\begin{tabular}{|c|c|c|c|c|c|c|c|c|}
\hline \multirow{2}{*}{$\begin{array}{l}\text { Research } \\
\text { Groups }\end{array}$} & \multicolumn{3}{|c|}{ Statistic Score } & \multirow{2}{*}{ Average } & \multirow{2}{*}{$\begin{array}{l}\text { Media } \\
\text { n }\end{array}$} & \multirow{2}{*}{$\begin{array}{l}\text { Modu } \\
\text { S }\end{array}$} & \multirow{2}{*}{ Variant } & \multirow{2}{*}{$\begin{array}{l}\text { Deviatio } \\
\text { n }\end{array}$} \\
\hline & n & Maximu & Minimu & & & & & \\
\hline A1 & 20 & 72,22 & 36,26 & 53,62 & 52,48 & 69,59 & 214,100 & 14,63 \\
\hline $\mathrm{A} 2$ & 20 & 66,08 & 37,14 & 50,29 & 50,73 & 59,06 & 57,6418 & 7,59 \\
\hline A3 & 20 & 52,05 & 41,52 & 46,08 & 45,47 & 44,15 & 8,7110 & 2,95 \\
\hline B1 & 30 & 72,22 & 41,52 & 56,55 & 54,68 & 51,17 & 94,4522 & 9,72 \\
\hline $\mathrm{B} 2$ & 10 & 53,80 & 36,26 & 43,45 & 42,84 & 47,66 & 20,2829 & 4,50 \\
\hline A1B1 & 10 & 72,22 & 62,57 & 67,66 & 68,27 & 69,59 & 10,2204 & 3,20 \\
\hline A1B2 & 10 & 42,40 & 36,26 & 39,59 & 39,77 & 40,65 & 4,2386 & 2,06 \\
\hline $\mathrm{A} 2 \mathrm{~B} 1$ & 10 & 66,08 & 48,54 & 55,47 & 54,68 & 59,06 & 30,1572 & 5,49 \\
\hline A2B2 & 10 & 53,80 & 37,14 & 45,12 & 45,47 & 47,66 & 32,0372 & 5,66 \\
\hline A3B1 & 10 & 52,05 & 41,52 & 46,52 & 45,47 & 49,42 & 13,8523 & 3,72 \\
\hline A3B2 & 10 & 48,54 & 42,40 & 45,64 & 45,47 & 45,03 & 4,1104 & 2,03 \\
\hline
\end{tabular}

Table 3. Summary of Data Normality Test Results

\begin{tabular}{|l|c|l|l|}
\hline \hline \multicolumn{1}{|c|}{ Groups } & Lhitung & Ltabel & \multicolumn{1}{|c|}{ Description } \\
\hline$A 1$ & 0,1781 & 0,1900 & Normal \\
\hline${ }^{\wedge} 2$ & 0,1724 & 0,1900 & Normal \\
\hline${ }^{3}$ & 0,1869 & 0,1900 & Normal \\
\hline$A_{1} B_{1}$ & 0,1788 & 0,2580 & Normal \\
\hline$A t B_{2}$ & 0,1334 & 0,2580 & Normal \\
\hline$A_{2} B-_{i}$ & 0,1324 & 0,2580 & Normal \\
\hline & 0,1334 & 0,2580 & Normal \\
\hline$A_{2} B^{\wedge}$ & 0,1655 & 0,2580 & Normal \\
\hline$A_{2} B_{2}$ & 0,1190 & 0,2580 & Normal \\
\hline
\end{tabular}

There is interaction between training method and leg power on dolyo chagi ability

Because Fhitung > Ftabei $(60,383>3,168)$ hence $\mathrm{H}_{0}$ was rejected, which means there is interaction between training method (A) and leg power (B), hence the interaction between training method (A) and leg power (B) affects dolyo chagi (Y) ability significantly.

\begin{tabular}{|c|c|c|c|c|c|}
\hline घumbण Variams! & बह & 8um gatuare & When Brathere & Fhauma & Pranes \\
\hline Faktor $A$ & 2 & 677368 & रम्ब.60 & $88.73 \%$ & $3.16 \%$ \\
\hline Faktoor A & 7 & $27572,65 \pi$ & $2+672.6397$ & $70 x, 7 a 5$ & 4.030 \\
\hline 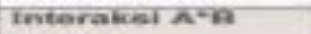 & 2 & 796-1.30\% & $\operatorname{sis} x, 102$ & od,ans & aiter \\
\hline Error & 50 & OS1,5ad & 15,760 & & \\
\hline Total & 50 & 5000,000 & & & \\
\hline
\end{tabular}


The average dolyo chagi ability on athletes with strong leg power, Plyometric training method (A1) is higher than with SAQ (A2)

From the Tukey calculation, it is shown that the score is qhitung $=12,19>$ qtabei $=$ 4,29 hence the average score of dolyo chagi ability (Y) with plyometric training method (A1) is different significantly with SAQ training method (A2) on the strong leg power (B1). The score is $\mathrm{gAiBi}=67,66>\mathrm{gA} 2 \mathrm{Bi}=55,47$ hence the average ability of dolyo chagi $(\mathrm{Y})$ with plyometric training method (A1) is higher than SAQ training method (A2).

The Average dolyo chagi ability on athletes with strong leg power, Plyometric training method (A1) is higher than with Circuit Training Method (A3)

From the Tukey calculation, it is shown that the score is qhitung $=21,14>$ qtabel $=4,29$ hence the average score of dolyo chagi ability $(\mathrm{Y})$ with plyometric training method (A1) is different significantly with circuit training method (A3) on the strong leg power (B1). The score is $\mathrm{gA} 1 \mathrm{~B} 1=67,66>\mathrm{gA} 3 \mathrm{~B} 1=46,52$ hence the average ability of dolyo chagi $(\mathrm{Y})$ with plyometric training method (A1) is higher than circuit training method (A3).

The Average dolyo chagi ability on athletes with strong leg power, SAQ training method (A2) is higher than with Circuit Training Method (A3)

From the Tukey calculation, it is shown that the score is qhitung $=8,95>$ qtabel $=4,29$ hence the average score of dolyo chagi ability (Y) with SAQ training method (A2) is different significantly with circuit training method (A3) on the strong leg power (B1). The score is $\mathrm{gA} 2 \mathrm{~B} 1=55,47>\mathrm{gA} 3 \mathrm{~B} 1=46,52$ hence the average ability of dolyo chagi $(\mathrm{Y})$ with SAQ training method (A2) is higher than circuit training method (A3).

The Average dolyo chagi ability on athletes with weak leg power, Plyometric training method (A1) is lower than with SAQ (A2)

From the Tukey calculation, it is shown that the score is qhitung $=5,52>$ qtabei $=4,29$ hence the average score of dolyo chagi ability $(\mathrm{Y})$ with plyometric training method (A1) is different significantly with SAQ training method (A2) on the weak leg power (B2). The score is gAiB2 $=39,59<\mathrm{gA} 2 \mathrm{~B} 2=45,12$ hence the average ability of dolyo chagi $(\mathrm{Y})$ with plyometric training method (A1) is lower than SAQ training method (A2).

The Average dolyo chagi ability on athletes with weak leg power, Plyometric training method (A1) is lower than with circuit training method (A3)

From the Tukey calculation, it is shown that the score is qhitung $=6,05>$ qtabel $=4,29$ hence the average score of dolyo chagi ability $(\mathrm{Y})$ with plyometric training method (A1) is different significantly with circuit training method (A3) on the weak leg power (B2). The score is gAiB2 $=39,59<\mathrm{gA} 3 \mathrm{~B} 2=45,64$ hence the average ability of dolyo chagi $(\mathrm{Y})$ with plyometric training method (A1) is lower than circuit training method (A3).

The Average dolyo chagi ability on athletes with weak leg power, SAQ training method (A2) is higher than with Circuit Training Method (A3)

From the Tukey calculation, it is shown that the score is qhitung $=0,53<$ qtabel 
$=4,29$ hence the average score of dolyo chagi ability (Y) with SAQ training method (A2) is different significantly with circuit training method (A3) on the weak leg power (B2). The score is gA2B2 $=45,12<\mathrm{MA} 3 \mathrm{~B} 2=45,64$ hence the average ability of dolyo chagi $(\mathrm{Y})$ with SAQ training method (A2) is lower than circuit training method (A3), but the difference is not significant.

\section{CONCLUSION}

Based on the data analysis results and discussion which was presented in CHAPTER IV, hence herewith the researcher will convey the research conclusion as follows: (1) Chagi on plyometric training, there are different effects among the three training methods on dolyo chagi ability. (2) There are different effects between strong leg power and weak leg power on dolyo chagi ability. (3) There an interaction between a training method and a leg power on dolyo chagi ability. (4) On strong leg power group, the dolyo chagi ability with plyometric training method is better than saq training method. (5) On the strong leg power group, dolyo chagi ability with plyometric training method is better than circuit training method. (6) On the strong leg power, dolyo chagi ability with saq training method is better than circuit training method. (7) On the athletes with weak leg power, the dolyo chagi ability with saq training method is better than plyometric training method. (8) the dolyo chagi ability with circuit training method is better than plyometric training method.

\section{REFERENCES}

Baechle, Thomas R. \& Roger W. Earle, Essentials of Strength Training and Conditioning. Champaign : Human Kinetics,2008.

Behnke, Robert S.Kinetic Anatomy .USA : Human Kinetics inc, 2006.

Bompa ,Tudor O. Periodization : Theory and Methodology of training $5^{\text {th }}$ edition. Champaign : Kendall /Hunt Publishing,2009.

Kinetic. 1999.

Bordiss, Sam (ed).Resistance Training : The Next Level .London :Baskervillie Press Ltd,2006.

Brich ,K and D Maclaren./nstant Notes in Sport and Exercise Physiology .New York : Madison Avenue,2005.

Brown ,Lee E.et al. Training for Speed Agility and Quickness.Champaign : Human Kinetics,2000.

Carr,Gerry.Sport Mechanics for Coaches. Champaign : Human kinetics, 2004.

Cocer ,Cheryl A. Motor Learning and Control for Practitioner. New York : Mc Graw Hill Companies, 2004.

Collins ,Paul.Speed for Sport .Oxford : Meyer Meyer Sport,2009.

Dawes Jay.Developing Agility and Quickness.USA : NSCA, 2012.

Dawson ,Catherine.A Practical Guide to Research Methods (Oxford : How to Books, 2007. 
Edward,William H. Motor Learnig and control from Theory to Practice.USA : Wadsworth, 2011.

Frost ,Robert.Applied Kinesiology A Training Manual and Refrence Book of Basic Principles and Practices. California : North Atlantic Books,2002.

Gallahue ,David L and John C. Ozmun. Understanding Motor Development. New York : Mc Graw Hill . 2006.

Hofman,Shirl J.Introduction to Kinesiology.Champaign : Human Kinetics, 2009.

Jay,Hoffman. Norms For Fitness Performance and Health. Champaign : Human Kinetic, 2006.

Jeffreys ,Ian. Developing Speed.Champaign : Human Kinetics, 2013.

Martens ,Rainers. Successful Coaching. Hong Kong : Human Kinetic,2004.

Paulus Levinus Pesurnay. Pengembangan Biomotorik.Disampaikan pada Penyegaran Pelatih PON XVI . Lampung : KONI, 2008.

Pottle ,Bill \& Katie Pottle. TAEKWONDO:A Practical Guide to the World's MostPopular Martial Art .USA : E Book, 2013.

Shumway ,Cook Anne \& Narjorie Woollacott. Motor Control. USA : Lippincott William \& Wilkin,2001.

Shepherd,John (ed). Periodisation : Planning YourTraining forPeak Performance. London : PLP Commercial Printers, 2009.

. Speed Training for All Sports.London : Electric

Word plc,2007.

Suranto. Anatomi Manusia (Modul). Lampung : STKIP Dharma Wacana Metro, 2004

Tangkudung James. Ilmu Faal (Fisiologi) . Jakarta : Cerdas Jaya, 2006.

Yoyok Surjadi. Taekwondo Pomsae. Jakarta : PT.Gramedia Pustaka Utama,2002. 